\title{
Mitochondrial DNA-RFLP analysis reveals low levels of genetic variation in European bison Bison bonasus
}

\author{
Ralph TIEDEMANN, Karl NADLINGER and Zdzisław PUCEK
}

\begin{abstract}
Tiedemann R., Nadlinger K. and Pucek Z. 1998. Mitochondrial DNA-RFLP analysis reveals low levels of genetic variation in European bison Bison bonasus. [In: Ecological genetics in mammals III. G. B. Hartl and J. Markowski, eds]. Acta Theriologica, Suppl. 5: $83-87$.

Originating from only 12 individuals, the extant population of the European bison Bison bonasus (Linnaeus, 1758) has been severely bottlenecked and consequently exhibits a high degree of inbreeding. Previous studies of allozyme variation are to some extent contradictory regarding levels of genetic variation. However, they brought about evidence for a genetic depletion at nuclear loci. In this study, we investigated the mitochondrial DNA (mtDNA) of 26 specimens of European bison from Białowieża Primeval Forest, Eastern Poland. All of them showed the same mitochondrial haplotype. An evaluation of the analytical power of the applied method showed, that it might be suitable to detect major mitochondrial lineages, though rare haplotypes might be overlooked. The absence of detected genetic variation in the mtDNA is corroborated by a calculation of time until fixation of a single haplotype in European bison during the bottleneck, which might be less than 100 years. In conclusion, the low levels of nuclear and the absence of mitochondrial variation are in concordance with theoretical expectations for species, which have experienced a prolonged population bottleneck.
\end{abstract}

Institut für Haustierkunde, Christian-Albrechts-Universität zu Kiel, Olshausenstraße 40, D-24118 Kiel, Germany (RT, KN); Mammal Research Institute, Polish Academy of Sciences, 17-230 Białowieża, Poland (ZP)

Key words: Bison bonasus, prolonged bottleneck, power analysis

\section{Introduction}

The European bison Bison bonasus (Linneaus, 1758) is one of the most severely bottlenecked mammalian species of the world (cf Pucek 1991). Free-ranging populations of the species were extinct in Europe in 1919 (Pucek 1986). The extant world population of about 3200 individuals (cf Hartl and Pucek 1994) originates from 12 animals (4 males, 8 females), corresponding to an effective population size of $\mathrm{N}_{\mathrm{e}}=10.7$ (Slatis 1960). The bison population at Białowieża represents the last pure bred subspecies (B. b. bonasus) and originates from only 7 animals ( 4 males, 3 females, $\mathrm{N}_{\mathrm{e}}=6.9$, Olech 1989). Consequently, extant populations of European bison are highly inbred (Slatis 1960, Olech 1987, 1989). 
Two genetic studies on allozyme variation in European bison, based on 20-22 scored loci, estimated average heterozygosity $(H)$ to be about 3.5 to $4 \%$ (Gębczyński and Tomaszewska-Guszkiewicz 1987, Sipko et al. 1996), comparable in magnitude to values found in mammalian species presumably not bottlenecked (Tiedemann et al. 1996). On the contrary, a more thorough investigation on allozyme variation at 69 loci estimated $H$ to be $1.2 \%$ (Hartl and Pucek 1994), indeed indicative of a nuclear genetic depletion in the species. Moreover, a low proportion of polymorphic loci $(P)$ and a high $H: P$-ratio were detected, both being estimates presumably more sensitive to bottleneck effects (Hartl and Pucek 1994, Hartl et al. 1994, Tiedemann et al. 1996). This is corroborated by low genetic variation at a MHC locus in European bison (Udina and Shaikhaev 1998).

From a population genetic point of view, the mitochondrial DNA (mtDNA) is better suited to demonstrate bottleneck effects on genetic variation: Due to its maternal inheritance and its haploid state, effective population size with regard to mtDNA is only $1 / 4$ of $\mathrm{N}_{\mathrm{e}}$ with regard to nuclear genes (cf Avise 1994). Additionally, a depletion of genetic variation after a bottleneck retains in mtDNA, while variation is more rapidly regained in the nuclear genome ( $\mathrm{cf}$ Wilson et al. 1985). In this framework, our study aimed at a comparison of the genetic effects of a severe population bottleneck, as in European bison, on mitochondrial vs. nuclear DNA. Thus, an investigation of mtDNA variation was performed on a sample set which had already been screened for allozyme variability by Hartl and Pucek (1994).

\section{Material and methods}

Twenty-six specimens of European bison were sampled during regulation hunting in the Białowieża Forest, Eastern Poland. Mitochondrial DNA (mtDNA) was isolated from frozen liver samples according to standard methods (cf Hartl et al. 1993). A restriction fragment length polymorphism (RFLP) analysis was performed by digesting the mtDNA with 12 six-base cutting restriction enzymes (Apa I, Bam HI, Bcl I, Bgl II, Cla I, Eco RI, Hind III, Hpa I, Kpn I, Pst I, Sfu I, Xho I). Restriction fragments were separated by horizontal agarose gel electrophoresis and visualized through UV-fluorescence in the presence of Ethidiumbromide. Fragment size was estimated by comparison with a molecular size standard (Bacteriophage $\lambda$-DNA, Hind III restricted).

\section{Results}

The approximate size of the detected restriction fragments is given in Table 1. A total of 36 fragments were detected, corresponding to $216 \mathrm{bp}$ sequence or about $1.3 \%$ of the complete mtDNA screened in the present restriction sites altogether. All 26 analysed animals showed identical restriction patterns, ie no genetic variation was detected in the mitochondrial DNA. 
Table 1. Approximate size (bp) of detected restriction fragments of mtDNA in European bison.

\begin{tabular}{lrrrrrr}
\hline Enzyme & Apa I & Bam HI & Bcl I & Bgl II & Cla I & Eco RI \\
\hline Size of fragments & 10700 & 8900 & 6200 & 9700 & 9800 & 6500 \\
& 4400 & 5900 & 5000 & 6600 & 6500 & 4800 \\
& 1300 & 1500 & 3500 & & & 3600 \\
& & 500 & 900 & & & 1400 \\
\hline Enzyme & & 700 & & & \\
\hline \multirow{2}{*}{ Size of fragments } & 10200 & 6100 & 16400 & 15800 & 14100 & 12700 \\
& 3700 & 5100 & & 600 & 2300 & 3700 \\
& 1700 & 1700 & & & & \\
& 700 & 1700 & & & & \\
\end{tabular}

\section{Discussion}

\section{Analytical power of the applied method}

The lack of detected variation in the mitochondrial DNA of the analysed European bison specimens calls for a consideration of the power of the performed analysis, ie how probable is the detection of present genetic variation with the

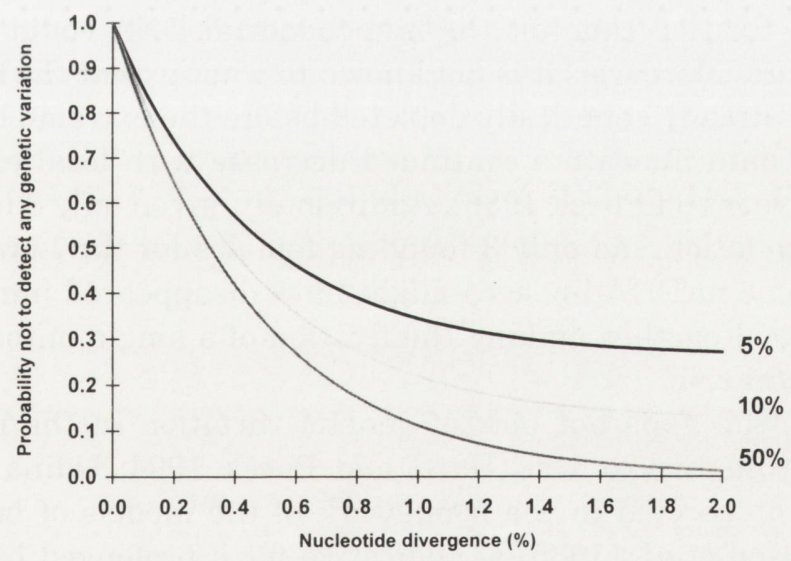

Fig. 1. Probability not to find a mitochondrial haplotype (B), which is different from the type (A) described in the present study as a function of sequence divergence among A and B. Probabilities are given for 3 different relative frequencies of $\mathrm{B}$ in the European bison population $(5,10$, and $50 \%$, respectively). For simplicity, it was assumed, that (a) no bias is present towards or against substitutions to occur in restriction sites and (b) the analysed sample set was representative for the European bison population. Calculations are based on $216 \mathrm{bp}$ out of $16400 \mathrm{bp}$ (total mtDNA) to be screened and 26 out of 3200 European bison to be analysed. 
applied method. If we assume for simplicity that (a) no bias is present towards or against substitutions to occur in restriction sites and (b) the analysed sample set was representative for the European bison population, we can calculate the probabilities not to detect a haplotype actually present in the population (B) which is different from the detected type (A) (Fig. 1). Obviously, these probabilities depend on the nucleotide divergence among $\mathrm{A}$ and $\mathrm{B}$ as well as on the relative frequency of $\mathrm{B}$ in the population (Fig. 1). The power of the performed analysis to detect haplotypes less than $0.5 \%$ divergent from $\mathrm{A}$ is apparently quite poor. However, the analytical power is over $80 \%$ to find both of two mitochondrial lineages, when these lineages show a divergence of $1 \%$ from one another and both of them have a relative frequency of at least $10 \%$ in the population. Hence, though the method is unlikely to detect rare haplotypes with few substitutions compared to the described type A, it has a reasonable power for detecting frequent major mitochondrial lineages. We thus conclude, that the absence of detected genetic variation among the analyzed part of the mitochondrial DNA is indicative of a very low genetic variation in mtDNA among European bison.

\section{Genetic depletion in the nuclear vs mitochondrial genome of European bison}

Since the effective population size with regard to mitochondrial DNA is only $1 / 4$ of $\mathrm{N}_{\mathrm{e}}$ with regard to nuclear genes, fixation in mtDNA is reached, on average, 4 times faster, ie after $\mathrm{N}_{\mathrm{e}}$ generations (Hartl and Clark 1989). Considering the very severe bottleneck in the European bison population at the beginning of this century, average fixation time for the mitochondrial DNA could be estimated to be within 100 years. Moreover, it is not known to what extent the bison population might have been already genetically depleted before the extreme bottleneck, since available census data indicate a continued decrease with local extinction during several hundred years (cf Pucek 1986). Additionally, given only 8 founding females for the whole population and only 3 founding females for the Lowland subspecies at Białowieża, some mtDNA lineages might have disappeared immediately due to stochastic effects, altogether making the fixation of a single mitochondrial haplotype a realistic scenario.

In conclusion, the apparent lack of genetic variation in the mtDNA and the genetic depletion at nuclear loci (Hartl and Pucek 1994; Udina and Shaikhaev 1997) might be interpreted in the framework of the models of bottleneck effects presented by Wilson et al. (1985) as indicative for a prolonged bottleneck, which - in theory - brings nuclear genetic variation to low levels and mtDNA variation to zero.

Acknowledgements: We thank Prof G. B. Hartl for the initiation and supervision of the investigation. Anita Haiden kindly provided technical assistance. 


\section{References}

Avise J. C. 1994. Molecular markers, natural history and evolution. Chapman and Hall, New York, London: $1-511$.

Hartl D. L. and Clark A. G. 1989. Principles of population genetics. 2nd ed. Sinauer, Sunderland: $1-682$.

Hartl G. B., Suchentrunk F., Nadlinger K. and Willing R. 1993. An integrative analysis of genetic differentiation in the brown hare (Lepus europaeus), based on morphology, allozymes, and mitochondrial DNA. [In: Ecological genetics in mammals. G. B. Hartl and J. Markowski, eds]: Acta Theriologica 38, Suppl. 2: 33-57.

Hartl G. B. and Pucek Z. 1994. Genetic depletion in the European bison (Bison bonasus) and the significance of electrophoretic heterozygosity for Conservation. Conservation Biology 8: 167-174.

Hartl G. B., Willing R. and Nadlinger K. 1994. Allozymes in mammalian population genetics and systematics: Indicative function of a marker system reconsidered. [In: Molecular ecology and evolution: approaches and applications. B. Schierwater, B. Streit, G. P. Wagner and R. DeSalle, eds]. Experientia Supplementum. Birkhäuser Verlag, Basel: 299-310.

Gębczyński M. and Tomaszewska-Guszkiewicz K. 1987. Genetic variability in the European bison. Biochemical Systematics and Ecology 15: 285-288.

Olech W. 1987. Analysis of inbreeding in European bison. Acta Theriologica 32: 373-387.

Olech W. 1989. The participation of ancestral genes in the existing population of European bison. Acta Theriologica 34: 397-407.

Pucek Z. 1986. Bison bonasus (Linnaeus, 1758) - Wisent. [In: Handbuch der Säugetiere Europas, Band 2/II Paarhufer. J. Niethammer and F. Krapp, eds]. Aula Verlag, Wiesbaden: 278-315.

Pucek Z. 1991. History of the European bison and problems of its protection and management. [In: Global trends in wildlife management. B. Bobek, K. Perzanowski and W. Regelin, eds]. Trans. 18th IUGB Congress, Kraków 1987. Świat Press, Kraków-Warszawa: 19-39.

Sipko T. P., Rautian G. S., Udina I. G. and Rakitskaya T. A. 1996. Polymorphism of biochemical markers in European bison (Bison bonasus). Genetika 32: 400-405. [In Russian with English summary]

Slatis M. A. 1960. An analysis of inbreeding in the European bison. Genetics 45: 275-287.

Tiedemann R., Hammer S., Suchentrunk F. and Hartl G. B. 1996. Allozyme variability in medium-sized and large mammals: determinants, estimators, and significance for conservation. Biodiversity Letters 3: 81-91.

Udina I. G. and Shaikhaev G. O. 1998. Restriction fragment length polymorphism (RFLP) of exon 2 of the MhcBibo-DRB3 gene in European bison (Bison bonasus). [In: Ecological genetics in mammals. G. B. Hartl and J. Markowski, eds]: Acta Theriologica, Suppl. 5: 75-82.

Wilson A. C., Cann R. L., Carr S. M., George M., Gyllensten U. B., Helm-Bychowski K. M., Higuchi R. G., Palumbi S. R., Prager E. M., Sage R. D. and Stoneking M. 1985. Mitochondrial DNA and two perspectives on evolutionary genetics. Biological Journal of the Linnean Society 26: 375-400.

Received 10 June 1998, accepted 30 June 1998. 